\title{
TIJAUAN SOSIOLOGIS DAN PSIKOLOGIS PASAL 7 AYAT 1 UNDANG-UNDANG NOMOR 1 TAHUN 1974 TENTANG PERKAWINAN
}

\section{Oleh : Ahmad Badi ${ }^{* *}$}

\begin{abstract}
Abstrak
Perkawinan ialah ikatan lahir batin antara seorang pria dengan seorang wanita sebagai suami istri dengan tujuan membentuk rumah tangga yang bahagia dan kekal. Inilah salah satu tujuan Undang-Undang Nomor 1 tahun 1974 tentang perkawinan Pasal 7 ayat 1 dirumuskan. Pada pasal dan ayat ini, diterangkan bahwa pasangan yang boleh melakukan perkawinan adalah jika pihak pria sudah mencapai umur 19 tahun dan pihak wanita berumur 16 tahun. Namun pada realitanya, kendatipun sudah mengikuti undang-undang tersebut, di Kabupaten Kediri pasangan muda menikah yang rentan dengan perceraian meningkat hingga $10-$ 20 pasangan. Faktor penyebab utamanya antara lain adalah masalah ekonomi dan kedewasaan kedua pasangan yang tidak lain adalah tujuan dari pembatasan usia nikah tersebut.

Berdasarkan penjelasan di atas dan juga atas perubahan sosiologis dan psikologis di masyarakat, kajian ulang terhadap pembatasan usia perkawinan dalam perundang-undangan tersebut penting dilkukan. Dari hasil kajian ini, penulis mengusulkan perubahan pembatasan usia perkawinan yaitu 25 tahun untuk lakilaki dan 22 tahun untuk perempuan.
\end{abstract}

Key Words: Aspek sosiologis, psikologis, batas usia perkawinan

* IAI Tribakti Kediri. 


\section{Pendahuluan}

Perkawinan merupakan salah satu sunnatullah untuk semua makhluk. Adapun khusus untuk manusia, Allah memberikan peraturan mengenai penyaluran syahwatnya, yakni melalui perkawinan Syar'i. Peraturan ini dimaksudkan agar supaya sesuai dengan kehormatannya, memelihara kemuliaan dan kesuciaannya serta untuk melanjutkan keturunannya.

Perkawinan ialah ikatan lahir batin antara seorang pria dengan seorang wanita sebagai suami istri dengan tujuan membentuk keluarga (rumah tangga) yang bahagia dan kekal berdasarkan Ketuhanan Yang Maha Esa. ${ }^{1}$ Salah satu prinsip yang dianut dalam Undang-Undang Perkawinan Republik Indonesia adalah prinsip kematangan calon mempelai. Di dalam Undang-Undang Nomor 1 tahun 1974 tentang perkawinan pada Pasal 7 ayat 1 menyatakan bahwa perkawinan hanya diizinkan jika pihak pria sudah mencapai umur 19 (sembilan belas) tahun dan pihak wanita sudah mencapai umur 16 (enam belas) tahun. Pada usia itu diasumsikan bahwa baik laki-laki maupun perempuan telah cukup matang untuk memasuki gerbang perkawinan dengan segala macam permasalahannya. Prinsip kematangan tersebut juga mempunyai tujuan luhur, yaitu menciptakan sikap tanggung jawab dan tolong-menolong. Selain itu, dengan adanya pembatasan usia tersebut, diharapkan laju perkembangan warga negara bisa dikontrol supaya tidak berkembang pesat.

Dalam hukum Islam, ketentuan usia seseorang bisa melangsungkan perkawinan tidak dijelaskan. Di dalam fiqih ketentuan yang ada hanya permasalahan akil balig bagi pria dan wanita. Dalam konteks perkawinan, standar akil balig sesorang belum bisa dijadikan acuan atau pertimbangan, karena perkawinan bukan persoalan akil balig saja, tetapi juga berkaitan

1 Defenisi tersebut berdasarkan pasal 1 Undang-Undang Republik Indonesia Nomor 1 tahun 1974 tentang Perkawinan. Sedangkan di dalam Kompilasi Hukum Islam dinyatakan bahwa perkawinan menurut hukum Islam adalah perkawinan, yaitu akad yang sangat kuat atau mitsaqan ghaliidzan, untuk menaati perintah Allah dan melaksanakannya merupakan ibadah. 
dengan kesiapan fisik, psikis dan ekonomi. Dalam hadisnya, Rasulullah bersabda:

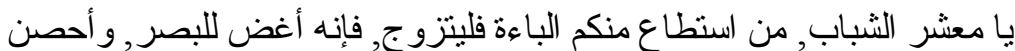

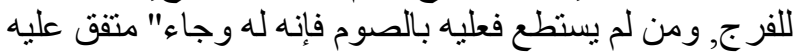

Artinya: "Wahai sekalian pemuda, barang siapa diantara kalian yang telah mampu hendaklah dia menikah, karena yang demikian itu lebih menjaga pandangan dan lebih menjaga kemaluannya, dan barang siapa yang belum mampu hendaklah dia berpuasa, karena itu merupakan benteng baginya" (Muttafaq Alaihi)

Hadis di atas memberi pemahaman kepada kita bahwa sebelum melaksanakan perkawinan, maka berkaitan dengan kemampuan, baik itu kesiapan secara ekonomi maupun mental.

Setelah melangsungkan perkawinan, bagaimana suami istri bisa bersama-sama membentuk keluarga yang saling mengasihi dan menyayangi. Dalam Kompilasi Hukum Islam pasal 3 dinyatakan bahwa perkawinan bertujuan untuk mewujudkan kehidupan rumah tangga yang sakinah, mawaddah dan rahmah. Hal ini sesuai firman Allah SWT:

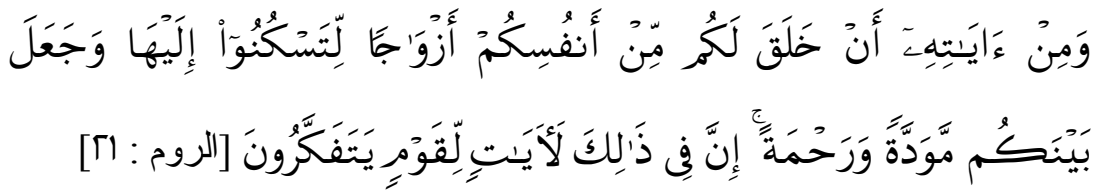

Terjemahnya: Dan di antara tanda-tanda kekuasaan-Nya ialah Dia menciptakan untukmu isteri-isteri dari jenismu sendiri, supaya kamu cenderung dan merasa tenteram kepadanya, dan dijadikan-Nya diantaramu rasa kasih dan sayang. Sesungguhnya pada yang demikian itu benarbenar terdapat tanda-tanda bagi kaum yang berfikir. (QS Al-Rum: 21$)^{2}$

Rumah tangga yang tentram, penuh kasih dan sayang di dalam keluarga tidak mudah untuk dilakukan. Hal ini berkaitan

\footnotetext{
${ }^{2}$ Al-Qur'an; 30, 21.
} 
dengan kedewasaan serta kesejahteraan keluarga. Maka dari itu, penting untuk mengkaji batas usia perkawinan dalam perspektif sosiologis dan psikologis.

\section{Defenisi Perkawinan}

Nikah adalah suatu akad yang menyebabkan kebolehan bergaul antara seorang laki-laki dengan seorang perempuan dan saling menolong di antara keduanya serta menentukan batas hak dan kwajiban di antara keduanya. ${ }^{3}$ Pengertian tersebut menyiratkan diperbolehkannya hubungan seksual, mengandung aspek hukum dan tolong menolong. Artinya orang yang menikah dihadapkan kepada tanggung jawab serta hak-hak yang dimilikinya.

Esensi yang terkandung dalam perkawinan adalah menaati perintah Allah serta sunnah Rasul, yaitu menciptakan suatu kehidupan rumah tangga yang mendatangkan kemaslahatan, baik bagi pelaku perkawinan, keturunan, kerabat maupun masyarakat. Oleh karena itu, perkawinan tidak hanya bersifat kebutuhan internal yang bersangkutan, tetapi mempunyai kaitan eksternal yang melibatkan banyak pihak. Sebagai suatu perikatan yang kokoh, perkawinan dituntut untuk menghasilkan suatu kemaslahatan yang kompleks, bukan hanya penyaluran biologis.

\section{Aspek dalam Perkawinan Aspek Personal}

Dalam aspek personal, minimal terdapat dua hal yang menjadi ruang lingkupnya, yaitu penyaluran kebutuhan biologis dan reproduksi generasi. Menurut fitrahnya, manusia dilengkapi Tuhan dengan kecendrungan seks (libido seksualitas). Manusia selalu hidup berpasangan akibat adanya daya tarik, nafsu syahwat di antara dua jenis kelamin yang berlainan. Maka kebutuhan manusia dalam bentuk ini perlu disalurkan pada proporsi yang tepat dan sah sesuai derajat kemanusiaan. Disamping itu, mendapatkan keturunan melalui perkawinan merupakan jalan yang baik dan sah sesuai dengan ajaran Islam.

\footnotetext{
2000), h. 13.

${ }^{3}$ Rahmat Hakim, Hukum Perkawinan Islam, (Bandung: Pustaka Setia, 


\section{Aspek Sosial}

Dalam aspek ini, bisa diidentifikasi dengan adanya membentuk rumah tangga yang baik sebagai fondasi masyarakat yang baik dan membuat manusia kreatif. Keluarga sebagai bagian dari struktur bangsa mempunyai kontribusi yang sangat penting bagi bangsa tersebut. Maka dari itu, kalau keluarga yang dibangun kokoh, harmonis dan sejahtera, maka bangsa tersebut juga akan kuat. Adapun kreatif diartikan bahwa perkawinan mengajarkan tanggung jawab yang menimbulkan keinginan untuk berubah menjadi baik dengan berbagai cara untuk membahagiakan keluarganya.

\section{Aspek Ritual}

Perkawinan adalah bagian dari syari'at Islam (ibadah) sebagai refleksi ketaatan makhluk kepada Khaliqnya, bagian yang tak terpisahkan dari seluruh ajaran agama dan bukan sekedar urusan administratif. Di samping itu, perkawinan merupakan sunnah Rasulullah yang lebih baik kita ikuti agar agama Islam dapat diteruskan oleh generasi kita selanjutnya.

\section{Aspek Moral}

Antara manusia dan hewan mempunyai salah satu persamaan, yaitu adanya libido seksualitas. Artinya, untuk memenuhi kebutuhan biologis, sama-sama melampiaskan kepada lawan jenisnya. Agar berbeda dengan hewan, manusia dituntut untuk mengikuti aturan atau norma-norma agama dan moralitas agama. Untuk itu, prkawinan adalah garis demarkasi yang membedakan manusia dengan hewan untuk menyalurkan kepentinngan yang sama.

\section{Aspek Kultural}

Kalau kita amati dalam praktek perkawinan, terkadang tidak cukup dengan persyaratan-persyaratan agama. Peristiwa keagamaan tersebut sudah terjadi akulturasi dengan budaya masyarakat, baik yang berupa simbul tradisi maupun yang lainnya.

\section{Usia Perkawinan Perspektif Sosiologis dan Psikologis}

Di dalam Undang-Undang Nomor 1 tahun 1974 tentang perkawinan pada Pasal 7 ayat 1 menyatakan bahwa perkawinan 
hanya diizinkan jika pihak pria sudah mencaai umur 19 (sembilan belas) tahun dan pihak wanita sudah mencapai umur 16 (enam belas) tahun. ${ }^{4}$

\section{Perspektif Sosiologis}

Peninjauan hukum secara sosiologis merupakan refleksi kehidupam masyarakat, yang unsurnya antara lain: a) Hukum merupakan refleksi dari kebiasaan, tabiat, dan perilaku masyarakat; b) Hukum merupakan refleksi, baik dari moralitas masyarakat maupun moralitas universal; dan c) Hukum merupakan refleksi dari kebutuhan masyarakat terhadap suatu keadilan dan ketertiban sosial dalam menata interaksi antar anggota masyarakat. ${ }^{5}$

Berkenaan dengan kajian sosiologis ini, ada beberapa hal yang perlu ditinjau, yaitu:

\section{Kekuatan Fisik}

Perkawinan merupakan peristiwa yang penting dan suci bagi perjalanan hidup manusia. Kehidupan baru perkawinan akan merubah status mereka, mempunyai tanggung jawab yang lebih berat, baik dalam keluarga maupun masyarakat. Seorang pria yang sudah menikah akan menjadi kepala keluarga dan mempunyai kewajiban untuk memberi nafkah kepada seluruh anggota keluarga, menjadi imam (dalam hal ibadah), dan menyelesaikan persoalan keluarga. ${ }^{6}$ Sedangkan seorang wanita ketika sudah menikah, ia akan melaksanakan kodratnya ${ }^{7}$ dan menjadi seorang ibu.

Tanggung jawab yang besar dipikul oleh suami istri setelah melakukan perkawinan, maka dari itu perlu adanya kesiapan fisik dan psikis. Dalam melaksanakan perkawinan, terdapat pekerjaan yang berat sehingga membutuhkan persiapan

${ }^{4}$ Dalam penjelasan pasal 7 ayat 1 disebutkan bahwa untuk menjaga kesehatan suami, istri dan keturunan, perlu ditetapkan batas-batas umur perkawinan

${ }_{5}$ Munir Fuady, Sosiologi Hukum Kontemporer, Interaksi Hukum, Kekuasaan, dan Masyarakat (Bandung: PT Citra Aditya Bakti, 2007), h. 28.

${ }^{6}$ Dalam memutuskan persolan, harus musyawarah dengan istri atan anak-anak. Tetapi keputusan akhir yang menetapkan seorang kepala keluarga.

${ }^{7}$ Di antara kodrat wanita adalah hamil, melahirkan serta menyusui. 
fisik dan psikis, karena hal ini bisa meminimalisir perselisihan bahkan perceraian dalam rumah tangga. Rumah tangga memerlukan persiapan fisik yang baik, seperti suami yang harus mencari nafkah dengan bekerja. Sedangkan istri, kesiapan fisik juga penting, selain bertanggung jawab atas pekerjaan rumah juga membutuhkan tenaga yang ekstra ketika dikaruniai keturunan.

Bagi laki-laki, ketahanan fisik lebih dituntut lagi karena posisinya merupakan pemimpin atau kepala rumah tangga. Lakilaki dituntut untuk mencukupi kebutuhan rumah tangga, istri serta anak-anaknya, baik kebutuhan primer maupun sekunder, juga memberi perlindungan kepada mereka. Ia harus mengeluarkan segenap potensi yang dimiliki untuk berupaya merealisasikan kewajibannya. Kewajiban seorang suami atas istri diterangkan oleh firman Allah SWT dalam al-Qur'an Surat Al-Thalaaq ayat 6-7. ${ }^{8}$ Ayat ini menerangkan bahwa seorang suami berkewajiban untuk mencukupi segala kebutuhan keluarga dan juga sebagai pemimpin keluaarga, yang tidak lain membutuhkan ketahanan fisik yang kuat.

Perkembangan Zaman dan Emansipasi

Ketika Undang-Undang Nomor 1 Tahun 1974 tentang perkawinan dibuat, mayoritas masyarakat masih bekerja di sawah dengan upah yang sedikit, dunia industri masih kecil, perkembangan teknologi dan informasi belum tumbuh pesat. Maka pada zaman itu, laki-laki dan perempuan menikah mayoritas di usia muda. Perkawinan ini biasanya menjadi keluarga besar dengan keturunan yang banyak dan kesejahteraan (ekonomi) keluarga tidak maksimal. Pada zaman sekarang, perkawinan di usia muda lebih berpeluang mengakibatkan perceraian. Hal ini disebabkan beberapa hal, seperti ekonomi keluarga yang belum mapan, masih mengedepankan ego (belum dewasa) dalam menghadapi permasalahan keluarga dan lain sebagainya.

Sekarang ini, sudah banyak ruang bagi perempuan untuk mengekspresikan potensi dan berperan dalam ruang publik. Banyaknya organisasi yang melibatkan perempuan, baik

\footnotetext{
${ }^{8}$ al-Qur'an; 65,6-7.
} 
Lembaga Swadaya Masyarakat (LSM) maupun partai politik ikut andil dalam mewadahi aspirasi perempuan. Bahkan beberapa LSM secara khusus mempunyai program tentang pendidikan maupun pemberdayaan perempuan.

Secara statistik, rata-rata usia perkawinan ideal adalah 25 tahun untuk perempuan dan 27 tahun untuk laki-laki. Usia tersebut diasumsikan dapat mengurangi perceraian, dan secara psikologis sudah terbilang lebih stabil dalam menyikapi banyak permasalahan dalam perkawinan. Menurut mantan kepala BKKBN, Sugiri Syarief, usia ideal untuk perempuan adalah di usia 20-35 tahun, sedangkan untuk laki-laki yaitu 25-40 tahun. ${ }^{9}$

\section{Tingkat Pendidikan}

Sasaran pendidikan adalah manusia, karena pendidikan bermaksud membantu peserta didik untuk menumbuhkembangkan potensi-potensi kemanusiaannya. ${ }^{10}$ Salah satu fungsi pendidikan adalah sebagai usaha untuk mengembangkan potensi individu dan sekaligus usaha untuk mewariskan nilai-nilai budaya, maka pendidikan juga menyangkut pembentukan kepribadian. Pendidikan berkaitan dengan usaha untuk mengubah sikap dan tingkah laku, sedangkan kepribadian berhubungan dengan pola tingkah laku. Kepribadian dapat dilihat dari empat (4) aspek muatannya. Pertama, aspek personalia, yaitu kepribadian dilihat dari pola tingkah laku lahir dan batin yang dimiliki seseorang. Kedua, aspek individualitas, yakni karakteristik atau sifat khas yang dimiliki seseorang yang membedakan dengan individu lainnya. Ketiga, aspek mentalitas, sebagai perbedaan yang berkaitan dengan cara berpikir atau gambaran pola pikir seseorang. Keempat, aspek identitas, yaitu kecendrungan seseorang untuk mempertahankan sikap dirinya dari pengaruh luar. Identitas merupakan karakteristik yang menggambarkan jati diri seseorang. 11

\footnotetext{
${ }^{9}$ http//wowheboh.org/usia-ideal-perkawinan/ diakses tanggal 1 Mei 2014.

10 Umar Tirtarahardja dan S.L. La Sulo, Pengantar Pendidikan, (Jakarta: PT Rineka Cipta, 2005), h. 1.

11 Jalaluddin dan Abdullah Idi, Filsafat Pendidikan, (Jogjakarta: ArRuzz Media, 2007), 190.
} 
Pada zaman sekarang, mencari pekerjaan lebih sulit, selain mempunyai pengalaman, juga mempertimbangkan jenjang pendidikan. Artinya, semakin rendah tingkat pendidikannya, maka penghasilan yang bisa dicapai dan semakin tinggi jenjang pendidikannya, maka dia bisa lebih leluasa untuk mencari dan memilih pekerjaan sehingga penghasilannya juga lebih banyak.

Seiring dengan kesetaraan hak laki-laki dan perempuan dalam memperoleh pendidikan, maka saat ini sudah banyak perempuan yang bisa menempuh pendidikan tinggi, bahkan menjadi profesor. Ketika di dalam Undang-Undang terdapat pembatasan usia minimal yaitu 16 tahun bagi perempuan dan 19 tahun bagi laki-laki, maka hal ini masih perlu untuk dikaji ulang.

Dalam konteks pendidikan di Indonesia, usia 19 tahun bagi laki-laki masih sangat muda. Kalau dia sudah bekerja (untuk yang lulus SMA, STM atau SMK), masih belum punya banya pengalaman dan hasil yang maksimal. Apalagi kalau meneruskan jenjang pendidikan, masih dalam proses belajar di strata 1 (S1). Bagi perempuan, usia 16 tahun adalah usia setelah menjalankan pendidikan SMP yang tentunya masih banyak hal yang bisa diraih, dicitakan dalam konteks pendidikan. Perempuan ketika sudah menikah dan menjadi ibu, mempunyai tanggung jawab yang besar, terutama dalam pengetahuan serta pola mendidik anak-anaknya. Untuk itu, ia harus mempunyai pengetahuan dan wawasan yang luas dan salah satu caranya adalah melalui proses pendidikan formal.

Berdasarkan beberapa pertimbangan di atas, maka menurut penulis, batas usia minimal bagi laki-laki adalah 25 tahun dan perempuan 22 tahun. Di usia 25 tahun, diasumsikan bahwa laki-laki tersebut sudah menyelesaikan jenjang pendidikan strata 1 (S1) dan sudah bekerja sekitar 3 tahun. Hal ini sudah dianggap mempunyai wawasan atau pengetahuan yang baik serta sudah mempunyai penghasilan.

Di samping itu, hal ini juga bisa mendorong salah satu dari program pemerintah tentang wajib belajar sampai SMA (usia 17 tahun) dan membantu pemerintah dalam mengontrol atau membatasi laju pertumbuhan warga negara. 


\section{Perspektif Psikologis}

Perkawinan tidak hanya membutuhkan kesiapan fisik, tetapi juga kesiapan psikis atau mental. Baik suami maupun istri harus sama-sama mempunyai karakter dewasa (psikis), kesabaran dan keuletan dalam mengarungi bahtera rumah tangga. Untuk menuju ke jenjang perkawinan, maka idealnya baik laki-laki maupun perempuan harus dewasa.

Menurut Lavinson, dalam proses perkembangan manusia, ia membedakan empat periode kehidupan, yaitu:

1. Masa anak dan masa remaja (0-22 tahun)

2. Masa dewasa awal (17-45 tahun)

3. Masa dewasa madya (40-65)

4. Masa dewasa akhir (60 ke atas)

Antara 17 dan 22 tahun seseorang ada di dua masa. Ia meninggalkan masa pra-dewasa dan memasuki masa dewasa awal yang mencangkup tiga periode, yaitu; pengenalan dengan dunia orang dewasa (22-28 tahun), di mana orang akan mencari tempat dalam dunia kerja dan dunia hubungan sosial untuk membentuk struktur kehidupan yang stabil. Pada usia antara 2833 tahun pilihan struktur kehidupan ini menjadi lebih tetap dan stabil.

Tugas-tugas perkembangan masa dewasa menurut santrok adalah :

\section{Efisiensi Fisik}

Tugas memperhatikan aspek fisik individu sudah menjadi hal yang biasa dalam setiap perkembangan. Namun, pada tahap masa dewasa seseorang tidak lagi mengedepankan penampilan sebagai mana yang pernah dilakukan ketika masa remaja, masa dewasa awal pun hampir tidak lagi memperhatikan penampilan imitative sebagai pusat perhatian utama, melainkan pandangan dalam aspek pekerjaan, membina rumah tangga yang sakinah, dan bermasyarakat dengan relasi yang baik merupakan tugas paling diutamakan. Disinilah efisiansi fisik orang dewasa bisa di lihat.

\section{Kemampuan Motorik}

Motorik masa dewasa adalah gerak aktif yang sudah tidak lagi bermain-main, menghabiskan waktu dengan hanya bersenang-senang. Kemampuan motoric masa dewasa lebih 
bersifat intelegensi, seperti pengamatan yang berhubungan dengan tingkah laku dan menyelesaikan banyak hal dengan waktu yang bersamaan adalah salah satu tugas motoric sama dewasa.

\section{Kemampuan Mental}

Disamping masa dewasa adalah masa produktif yang berkelanjutan maka proses kognitif yang beriringan dengan mental yang matang merupakan tugas masa dewasa baik dewasa awal ataupu masa dewasa akhir.

\section{Motifasi}

Masa dewasa adalah waktu dimana seseorang diharapkan memberi motifasi sesuai dengan fungsi dan tingkat usianya. Juga tidak menutup kemungkinan sebagai seorang yang memberi, akan memerlukan kekuatan untuk membuat motifasi terhadap orang lain agar tidak mengalami keimbangan pemikiran.

\section{Model peran}

Kemandirian seseorang pada masa dewasa merupakan tujuan yang terjadi pada saat terjadinya masa dewasa awal, sehingga pada tugasnya seseorang harus mampu berperan sebagai humanis yang bisa menjadi panutan (model) baik bagi orang lain khususnya bagi diri sendiri. ${ }^{12}$

Dewasa Awal merupakan masa dewasa atau satu tahap yang dianggap kritikal selepas alam remaja yang berumur dua puluhan (20-an) sampai tiga puluhan (30 an). Ia dianggap kritikal karena disebabkan pada masa ini manusia berada pada tahap awal pembentukan karir dan keluarga. Pada peringkat ini, seseorang perlu membuat pilihan yang tepat demi menjamin masa depannya terhadap pekerjaan dan keluarga. Pada masa ini juga seseorang akan menghadapi dilema antara pekerjaan dan keluarga. Berbagai masalah mulai timbul terutama dalam perkembangan karir dan juga hubungan dalam keluarga.Dan masalah yang timbul tersebut merupakan salah satu bagian dari perkembangan sosio-emosional.

12 John W. Santrok, Life Span Development: Perkembangan Masa Hidup, Edisi 5 Jilid 2. (Jakarta: Erlangga, 2002), h. 31. 
Sosio-emosional adalah perubahan yang terjadi pada diri setiap individu dalam warna afektif yang menyertai setiap keadaan atau perilaku individu. Menurut Teori Erikson, Tahap Dewasa Awal yaitu mereka di dalam lingkungan umur 20 an ke 30 an. Pada tahap ini manusia mulai menerima dan memikul tanggungjawab yang lebih berat. Pada tahap ini juga hubungan intim mulai berlaku dan berkembang.

Karakteristik perkembangan orang dewasa awal, yaitu: Perkembangan Fisik.

a. Perkembangan Fisik Masa Dewasa Awal

Dewasa awal adalah masa kematangan fisik dan psikologis. Menurut Anderson terdapat 7 ciri kematangan psikologi, ringkasnya sebagai berikut:

a. Berorientasi pada tugas, bukan pada diri atau ego; minat orang matang berorientasi pada tugas-tugas yang dikerjakannya,dan tidak condong pada perasaanperasaan diri sendri atau untuk kepentingan pribadi.

b. Tujuan-tujuan yang jelas dan kebiasaan-kebiasaan kerja yang efesien; seseorang yang matang melihat tujuantujuan yang ingin dicapainya secara jelas dan tujuantujuan itu dapat didefenisikannya secara cermat dan tahu mana pantas dan tidak serta bekerja secara terbimbing menuju arahnya.

c. Mengendalikan perasaan pribadi; seseorang yang matang dapat menyetir perasaan-perasaan sendiri dan tidak dikuasai oleh perasaan-perasaannya dalam mengerjakan sesuatu atau berhadapan dengan orang lain. Dia tidak mementingkan dirinya sendiri, tetapi mempertimbangkan pula perasaan-perasaan orang lain.

d. Keobjektifan; orang matang memiliki sikap objektif yaitu berusaha mencapai keputusan dalam keadaan yang bersesuaian dengan kenyataan.

e. Menerima kritik dan saran; orang matang memiliki kemauan yang realistis, paham bahwa dirinya tidak selalu benar, sehingga terbuka terhadap kritik-kritik dan saran-saran orang lain demi peningkatan dirinya.

f. Pertanggungjawaban terhadap usaha-usaha pribadi; orang yang matang mau memberi kesempatan pada orang lain membantu usahan-usahanya untuk mencapai tujuan. 
Secara realistis diakuinya bahwa beberapa hal tentang usahanya tidak selalu dapat dinilainya secara sungguhsunguh, sehingga untuk itu dia bantuan orang lain, tetapi tetap dia brtanggungjawab secara pribadi terhadap usaha-usahanya.

g. Penyesuaian yang realistis terhadap situasi-situasi baru; orang matang memiliki ciri fleksibel dan dapat menempatkan diri dengan kenyataan-kenyataan yang dihadapinya dengan situasi-situasi baru. ${ }^{13}$

Ciri-ciri perkembangan dewasa awal adalah:

a. Usia reproduktif (Reproductive Age)

Masa dewasa adalah masa usia reproduktif. Masa ini ditandai dengan membentuk rumah tangga.Tetapi masa ini bisa ditunda dengan beberapa alasan. Ada beberapa orang dewasa belum membentuk keluarga sampai mereka menyelesaikan dan memulai karir mereka dalam suatu lapangan tertentu.

b. Usia memantapkan letak kedudukan (Setting down age)

Dengan pemantapan kedudukan (settle down), seseorang berkembangan pola hidupnya secara individual, yang mana dapat menjadi ciri khas seseorang sampai akhir hayat. Situasi yang lain membutuhkan perubahan-perubahan dalam pola hidup tersebut, dalam masa setengah baya atau masa tua, yang dapat menimbulkan kesukaran dan gangguangangguan emosi bagi orang-orang yang bersangkutan.

Ini adalah masa dimana seseorang mengatur hidup dan bertanggungjawab dengan kehidupannya. Pria mulai membentuk bidang pekerjaan yang akan ditangani sebagai karirnya, sedangkan wanita muda diharapkan mulai menerima tanggungjawab sebagai ibu dan pengurus rumah tangga.

c. Usia Banyak Masalah (Problem age)

Masa ini adalah masa yang penuh dengan masalah. Jika seseorang tidak siap memasuki tahap ini, dia akan kesulitan dalam menyelesaikan tahap perkembangannya. Persoalan yang dihadapi seperti persoalan pekerjaan/jabatan, persoalan

13 Andi Mappire. Psikologi Orang Dewasa (Surabaya: Usaha Nasional, 1983), h. 55. 
teman hidup maupun persoalan keuangan, semuanya memerlukan penyesuaian di dalamnya.

d. Usia tegang dalam hal emosi (emostional tension)

Banyak orang dewasa muda mengalami kegagalan emosi yang berhubungan dengan persoalan-persoalan yang dialaminya seperti persoalan jabatan, perkawinan, keuangan dan sebagainya. Ketegangan emosional seringkali dinampakkan dalam ketakutan-ketakutan atau kekhawatirankekhawatiran. Ketakutan atau kekhawatiran yang timbul ini pada umumnya bergantung pada ketercapainya penyesuaian terhadap persoalan-persoalan yang dihadapi pada suatu saat tertentu, atau sejauh mana sukses atau kegagalan yang dialami dalam pergumulan persoalan.

e. Masa keterasingan sosial

Dengan berakhirnya pendidikan formal dan terjunnya seseorang ke dalam pola kehidupan orang dewasa, yaitu karir, perkawinan dan rumah tangga, hubungan dengan teman-teman kelompok sebaya semakin menjadi renggang, dan berbarengan dengan itu keterlibatan dalam kegiatan kelompok diluar rumah akan terus berkurang. Sebai akibatnya, untuk pertama kali sejak bayi semua orang muda, bahkan yang populerpun, akan mengalami keterpencilan sosial atau apa yang disebut krisis ketersingan.

f. Masa komitmen

Mengenai komitmen, Bardwick seperti yang dikutip Hurlock mengatakan: "Nampak tidak mungkin orang mengadakan komitmen untuk selama-lamanya. Hal ini akan menjadi suatu tanggungajwab yang trrlalu berat untuk dipikul. Namun banyak komitmen yang mempunyai sifat demikian: Jika anda menjadi orangtua menjadi orang tua untuk selamanya; jika anda menjadi dokter gigi, dapat dipastikan bahwa pekerjaan anda akan terkait dengan mulut orang untuk selamanya; jika anda mencapai gelar doktor, karena ada prestasi baik disekolah sewaktu anda masih muda, besar kemungkinan anda sampai akhir hidup anda akan berkarier sebagai guru besar". ${ }^{14}$

${ }^{14}$ Hurlock, E.B.. Development Psychology. (New York: Mc GrawHill, Inc. 1980), h. 250. 
g. Masa Ketergantungan

Masa dewasa awal ini adalah masa dimana ketergantungan pada masa dewasa biasanya berlanjut. Ketergantungan ini mungkin pada orangtua, lembaga pendidikan yang memberikan beasiswa sebagian atau sepenuh atau pada pemerintah karena mereka memperoleh pinjaman untuk membiayai pendidikan mereka.

h. Masa perubahan nilai

Beberapa alasan terjadinya perubahan nilai pada orang dewasa adalah karena ingin diterima pada kelompok orang dewasa, kelompok-kelompok sosial dan ekonomi orang dewasa.

i. Masa Kreatif

Bentuk kreativitas yang akan terlihat sesudah orang dewasa akan tergantung pada minat dan kemampuan individual, kesempatan untuk mewujudkan keinginan dan kegiatan-kegiatan yang memberikan kepuasan sebesarbesarnya. Ada yang menyalurkan kreativitasnya ini melalui hobi, ada yang menyalurkannya melalui pekerjaan yang memungkinkan ekspresi kreativitas.

Berdasarkan penjelasan di atas, menurut penulis, usia 19 tahun bagi laki-laki dan 16 tahun bagi perempuan masih dalam tahap remaja, yang masih labil secara emosional. Dalam perkawinan di usia remaja, hal ini seringkali menimbulkan perselisihan, kurang menghargai perbedaan, mengakibatkan pertengkaran bahkan perceraian. Maka usia ideal bagi laki-laki maupun perempuan, adalah ketika mereka sudah masuk dalam tahap dewasa, yaitu 25 tahun bagi laki-laki dan 22 tahun bagi perempuan.

\section{Kesimpulan}

Pembatasan usia perkawinan yang tercantum perundangundangan perlu dikaji ulang. Secara sosiologis, masyarakat sudah mengalami perkembangan, baik dalam konteks relasi sosial (perkembangan teknologi dan informasi), industrialisasi, serta tingkat pendidikan meningkat. Di samping itu, secara psikologis, fase usia yang ideal untuk membangun kehidupan rumah tangga adalah fase dewasa awal. Hal ini karena di dalam 
fase tersebut dianggap sudah memiliki kematangan emosional dan tanggung jawab.

Menikah dengan usia dewasa serta telah memiliki bekal pengetahuan yang cukup serta pengalaman kerja, maka harapan untuk membina keluarga yang sakinah, mawaddah dan rahmah semakin besar peluangnya untuk dicapai. Untuk itu, menurut penulis, batas usia minimal untuk melangsungkan perkawinan adalah 25 tahun bagi laki-laki dan 22 tahun bagi perempuan. 


\section{DAFTAR PUSTAKA}

Fuady, Munir. Sosiologi Hukum Kontemporer, Interaksi Hukum, Kekuasaan, dan Masyarakat. Bandung: PT Citra Aditya Bakti, 2007.

Hakim, Rahmat. Hukum Perkawinan Islam. Bandung: Pustaka Setia, 2000.

Hurlock, E.B.. Development Psychology. New York: Mc GrawHill, Inc. 1980.

Jalaluddin dan Abdullah Idi, Filsafat Pendidikan. Jogjakarta: Ar-Ruzz Media, 2007.

Mappire, Andi. Psikologi Orang Dewasa. Surabaya: Usaha Nasional, 1983.

http//wowheboh.org/usia-ideal-perkawinan

Santrok, John W. Life Span Development: Perkembangan Masa Hidup, Edisi 5 Jilid 2. Jakarta: Erlangga, 2002.

Tirtarahardja, Umar dan S.L. La Sulo, Pengantar PendidikaN. Jakarta: PT Rineka Cipta, 2005. 